\title{
Knowledge Management Enablers and Its Impact on the Performance Outcomes of State Universities in the Philippines
}

\author{
Rainer R. Fiscal \\ College of Teacher Education, Laguna State Polytechnic University, Siniloan, 4019, Laguna, Philippines
}

Received December 7, 2020; Revised February 18, 2021; Accepted February 26, 2021

\section{Cite This Paper in the following Citation Styles}

(a): [1] Rainer R. Fiscal, "Knowledge Management Enablers and Its Impact on the Performance Outcomes of State Universities in the Philippines," Universal Journal of Management, Vol. 9, No. 2, pp. 44 - 51, 2021. DOI: 10.13189/ujm.2021.090203.

(b): Rainer R. Fiscal (2021). Knowledge Management Enablers and Its Impact on the Performance Outcomes of State Universities in the Philippines. Universal Journal of Management, 9(2), 44 - 51. DOI: 10.13189/ujm.2021.090203.

Copyright $\bigcirc 2021$ by authors, all rights reserved. Authors agree that this article remains permanently open access under the terms of the Creative Commons Attribution License 4.0 International License

\begin{abstract}
The main objective of this study is to investigate the relationship between knowledge management enablers and performance outcomes in higher education institutions in the Philippines particularly state universities. The population of the study was the faculty members of three selected state universities. Simple random sampling was utilized to select the samples. The sample size of the study was 150 and all the 150 questionnaires were useful for the aim of this study and making the response rate of $100 \%$. The reliability of data was tested by Cronbach's alpha and regression analysis was used to test the hypotheses. Results revealed that employee management has positive and significant impacts on teaching, research, citation, international outlook, and industry income. The same results are determined with organizational culture except for industry income. Information technology has positive and significant impacts on international outlook and industry income while leadership has negative and significant impacts on international outlook. This study concludes that employee motivation was a predictor of performance in teaching, research, citation, international outlook, and industry income. Organizational culture was a predictor of teaching, research, citation, and international outlook. Information technology was a predictor of international outlook and industry income and leadership was only a predictor of international outlook but negatively. The findings of this study may be utilized by higher education institutions in decision making to develop policies in achieving better
\end{abstract}

performance outcomes.

Keywords Knowledge Management, Performance Outcomes, State University

\section{Introduction}

Knowledge Management (KM) is a strategy applied by different organizations on how to get a right knowledge from the right people to ensure that knowledge can be shared and transferred to improve the performance outcomes [1]. KM is a major source of competitiveness to achieve the vision, mission, goals and objectives of the organization [2-4]. KM is a set of latest activities aimed for knowledge improvement, knowledge-related practices, organizational behaviors and decisions, and organizational performance [5]. Likewise, KM is a tool which helps the organizations to utilize resources more smartly and efficiently in able to achieve higher productivity. Also, KM is a task of developing and exploiting tangible (research outputs, strategic plan) and intangible (competencies and knowledge of employees) knowledge resources [6]. From the development of $\mathrm{KM}, \mathrm{KM}$ became popular in most advanced countries and in the third world the popularity is still limited [7], like in the Philippines.

$\mathrm{KM}$ was not only applicable in the business sector but also in the higher education institutions [8]. The 
competitiveness and innovativeness of HEIs may retain through KM strategies initiatives [9]. HEIs all over the world are in charged in knowledge generation, transmission, dissemination, and application for improve quality services [10] and their quality of performance outcomes can improve through KM [11-13]. Universities may apply KM to improve processes in research, curriculum development, student and alumni services and strategic planning [14]. Application of KM in the educational organizations can lead to better decision making, better instructions, effective networking, quality research, and easy access to scientific resources [15].

HEIs KM important factors are identified as the main driving forces of success such as culture, values, organizational structures, infrastructures [16], reward systems, networks, repositories [17], human resources [18], top management, leadership [19], organizational adjustments, and employee motivation [20].

$\mathrm{KM}$ practices in HEIs greatly affect organizational performance in innovation, growth, and competitive advantage [21]. KM practices also improve the quality of education [22] and provide better services to their stakeholders [23]. To achieve high performance, HEIs should apply support, communication, and learning management systems [24]. KM improves decision-making, handling students and staff, addressing key educational issues, employee skills, productivity, sharing best practices, costing, working conditions, staff attraction/retention, intellectual capital, communication, innovation and creativity, learning/adaptation capability, employees' empowerment, collaborations, and administrative processes [25].

Studies about KM and performance in the higher education institutions are few [7]. The Philippines as country with the highest number of higher education institutions [26], KM literatures are very limited. This reality motivates the researcher to conduct study on KM and Performance Outcomes. Ramachandran et al. [27] identified strategy and leadership, organizational culture, information technology, and performance measurement as the knowledge management enablers. These popular KM enablers are adopted to guide this study. Since the performance of all universities around the world is measured through teaching, research, citation, international outlook, and industry income [28], these performance outcomes are also adopted to guide the study. This research paper aims to explore on how KM enablers (organizational culture, leadership, information technology, and employee motivation) impacts Performance Outcomes (teaching, research, citation, international outlook, and industry income) in state universities in the Philippines.

\section{Research Model}

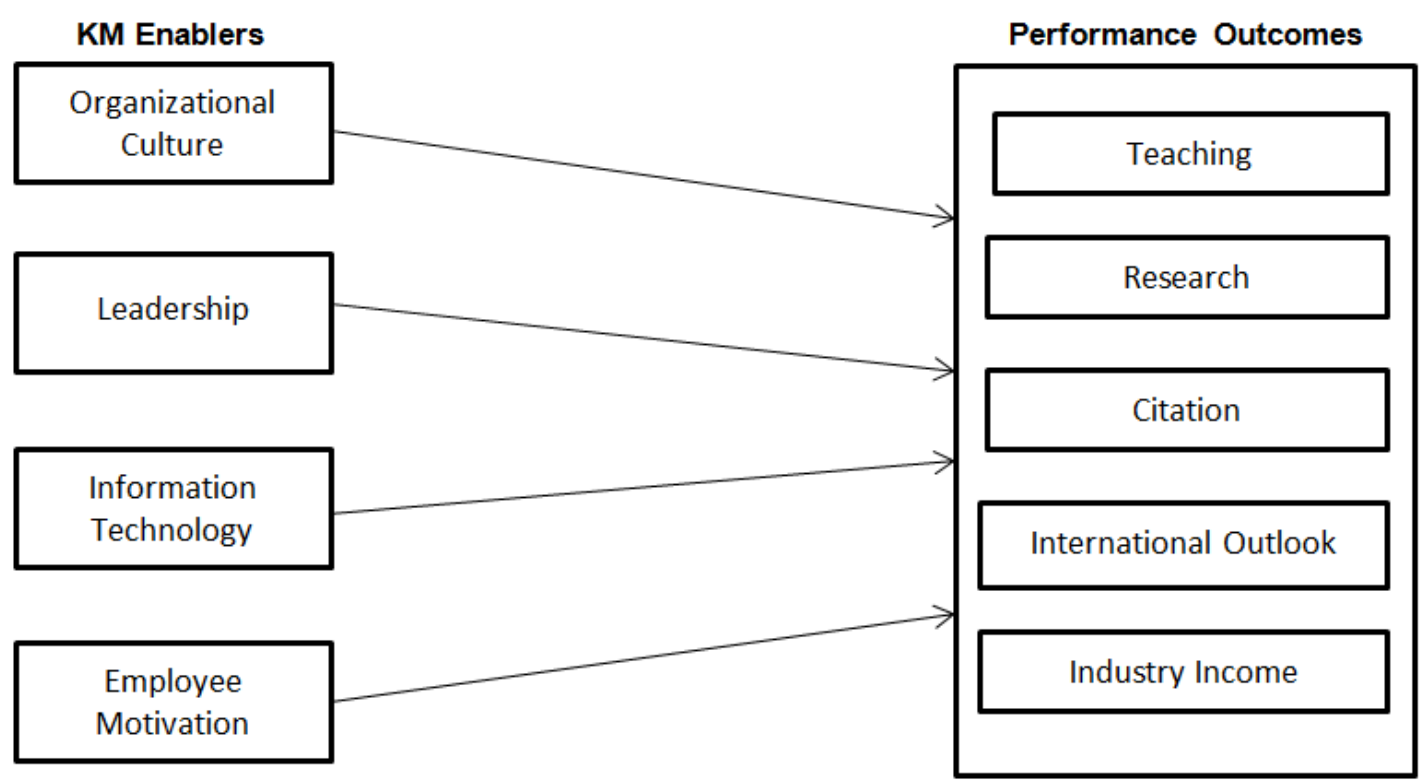




\section{Methodology}

The research instrument or survey questionnaire used in this study was developed and adopted from Ramachandran et al. [17] which contain forty-six questions on KM enablers (15 from organizational culture, 11 from leadership, 10 from information technology, and 10 from employee motivation) which are measured on seven-point Likert scale. Tool to measure organizational performance was developed and adopted from Times Higher Education [18] which contains twenty-one questions on organizational performance (5 from teaching, 4 from research, 3 from citation, 3 from international outlook, and 6 from industry income) which are also measured on seven-point Likert scale. The instrument was composed of three parts: first part entails questions regarding demographic characteristics of the respondents, the second and third parts consists of questions about KM enablers and performance outcomes. The research instrument or survey questionnaire was distributed to thirty samples in one state university in the Philippines for the pilot study before the questionnaire delivered to the targeted respondents. This pilot study gathered comments and feedbacks that help improved the quality of questionnaire.

This research was cross-sectional in nature that allows data collection at one point in time. Descriptive survey is the research design and the quantitative technique was applied in the conduct of this research. The data were collected from three Philippine state universities in three major groups of islands (Luzon, Visayas, and Mindanao) for about four months. The sample size of the study was one hundred fifty. The questionnaires were personally distributed to the faculty members of each selected state university through simple random sampling technique with the help of Office of the University President, Vice President for Research, Director for Research, and Office of the Deans. One hundred fifty questionnaires were returned and no questionnaires discarded making the response rate of one hundred percent. Analysis of the test was performed by using SPSS version 23 . The validity of the questionnaire was validated by the experts and reliability was computed by Cronbach's alpha.

\section{Results}

Reliability is presented in Table 1 and indicates that the internal consistency was reliable because the Cronbach's Alpha value for all the items exceeded the minimum 0.7 cut-off point [29].

Table 1. Reliability

\begin{tabular}{|c|c|c|}
\hline Variables & Cronbach's Alpha & Interpretation \\
\hline $\begin{array}{c}\text { Organizational } \\
\text { Culture }\end{array}$ & 0.968 & High Reliable \\
\hline Leadership & 0.980 & High Reliable \\
\hline $\begin{array}{c}\text { Information } \\
\text { Technology }\end{array}$ & 0.983 & High Reliable \\
\hline $\begin{array}{c}\text { Employee } \\
\text { Motivation }\end{array}$ & 0.978 & High Reliable \\
\hline Teaching & 0.962 & High Reliable \\
\hline Research & 0.974 & High Reliable \\
\hline Citation & 0.987 & High Reliable \\
\hline $\begin{array}{c}\text { International } \\
\text { Outlook }\end{array}$ & 0.951 & High Reliable \\
\hline Industry Income & 0.975 & High Reliable \\
\hline
\end{tabular}

Correlation is shown in Table 2. The result indicates that all KM enablers have positive correlation with performance outcomes (PO). Employee motivation (OM) has strong correlation with PO $(\mathrm{r}=0.755)$, OC has second strong correlation with PO $(\mathrm{r}=0.651)$, IT have third strong correlation with PO $(\mathrm{r}=0.646)$, and LD has the fourth strong correlation with PO $(\mathrm{r}=0.612)$ respectively.

The findings indicate that among the four KM enablers, EM $(57.0 \%)$ has the greatest contribution on teaching, research, citations, international outlook, and industry income followed by OC (42.4\%), IT (41.7\%), and LD $(37.5 \%)$ respectively. On the average, $55.8 \%$ of performance outcomes are related to KM enablers.

Table 2. Pearson Correlations

\begin{tabular}{|c|c|c|c|c|c|c|c|c|c|c|}
\hline & \multicolumn{10}{|c|}{ KM Enablers } \\
\hline & \multicolumn{5}{|c|}{ Organizational Culture } & \multicolumn{5}{|c|}{ Leadership } \\
\hline $\begin{array}{c}\text { Performance } \\
\text { Outcomes }\end{array}$ & Teaching & Research & Citation & $\begin{array}{c}\text { International } \\
\text { Outlook }\end{array}$ & $\begin{array}{l}\text { Industry } \\
\text { Income }\end{array}$ & Teaching & Research & Citation & $\begin{array}{c}\text { International } \\
\text { Outlook }\end{array}$ & $\begin{array}{l}\text { Industry } \\
\text { Income }\end{array}$ \\
\hline Pearson-r & .678 & .611 & .545 & .584 & .554 & .657 & .591 & .489 & .482 & .589 \\
\hline \multirow[t]{3}{*}{ P-value } & .000 & .000 & .000 & .000 & .000 & .000 & .000 & .000 & .000 & .000 \\
\hline & \multicolumn{10}{|c|}{ KM Enablers } \\
\hline & \multicolumn{5}{|c|}{ Information Technology } & \multicolumn{5}{|c|}{ Employee Motivation } \\
\hline $\begin{array}{c}\text { Performance } \\
\text { Outcomes }\end{array}$ & Teaching & Research & Citation & $\begin{array}{c}\text { International } \\
\text { Outlook }\end{array}$ & $\begin{array}{l}\text { Industry } \\
\text { Income }\end{array}$ & Teaching & Research & Citation & $\begin{array}{c}\text { International } \\
\text { Outlook }\end{array}$ & $\begin{array}{l}\text { Industry } \\
\text { Income }\end{array}$ \\
\hline Pearson-r & .591 & .601 & .531 & .576 & .649 & .715 & .734 & .669 & .617 & .720 \\
\hline $\mathrm{P}$-value & .000 & .000 & .000 & .000 & .000 & .000 & .000 & .000 & .000 & .000 \\
\hline
\end{tabular}


Table 3. Regression Analysis

\begin{tabular}{|c|c|c|c|c|c|}
\hline Predictors & Dependent Variable & $\mathrm{R}$ & R Square & $\begin{array}{c}\text { Adjusted R } \\
\text { Square }\end{array}$ & $\begin{array}{l}\text { Std. Error of } \\
\text { the Estimate }\end{array}$ \\
\hline \multirow{5}{*}{$\begin{array}{c}\text { Organizational Culture (OC), } \\
\text { Leadership (LD), } \\
\text { Information Technology (IT), Employee } \\
\text { Motivation (EM) }\end{array}$} & Teaching & .753 & .568 & .556 & .70603 \\
\hline & Research & .745 & .555 & .542 & .74556 \\
\hline & Citation & .685 & .469 & .455 & .81708 \\
\hline & International Outlook & .673 & .453 & .438 & .94610 \\
\hline & Industry Income & .736 & .542 & .529 & .72347 \\
\hline
\end{tabular}

Table 4. ANOVA Models

\begin{tabular}{|c|c|c|c|c|c|c|c|}
\hline \multicolumn{3}{|c|}{ Model } & $\begin{array}{l}\text { Sum of } \\
\text { Squares }\end{array}$ & $\mathrm{Df}$ & $\begin{array}{l}\text { Mean } \\
\text { Square }\end{array}$ & $\mathrm{F}$ & Sig. \\
\hline OC, LD, IT, EM & Teaching & $\begin{array}{c}\text { Regression } \\
\text { Residual } \\
\text { Total }\end{array}$ & $\begin{array}{c}94.897 \\
72.279 \\
167.176\end{array}$ & $\begin{array}{c}4 \\
145 \\
149\end{array}$ & $\begin{array}{c}23.724 \\
.498\end{array}$ & 47.594 & .000 \\
\hline OC, LD, IT, EM & Research & $\begin{array}{c}\text { Regression } \\
\text { Residual } \\
\text { Total }\end{array}$ & $\begin{array}{c}100.401 \\
80.599 \\
181.000\end{array}$ & $\begin{array}{c}4 \\
145 \\
149\end{array}$ & $\begin{array}{c}25.100 \\
.556\end{array}$ & 45.156 & .000 \\
\hline OC, LD, IT, EM & Citation & $\begin{array}{c}\text { Regression } \\
\text { Residual } \\
\text { Total } \\
\end{array}$ & $\begin{array}{c}85.578 \\
96.805 \\
182.384 \\
\end{array}$ & $\begin{array}{c}4 \\
145 \\
149 \\
\end{array}$ & $\begin{array}{c}21.395 \\
.668\end{array}$ & 32.046 & .000 \\
\hline OC, LD, IT, EM & $\begin{array}{c}\text { International } \\
\text { Outlook }\end{array}$ & $\begin{array}{c}\text { Regression } \\
\text { Residual } \\
\text { Total }\end{array}$ & $\begin{array}{l}107.387 \\
129.780 \\
237.177\end{array}$ & $\begin{array}{c}4 \\
145 \\
149 \\
\end{array}$ & $\begin{array}{c}26.847 \\
.895\end{array}$ & 29.993 & .000 \\
\hline OC, LD, IT, EM & Industry Income & $\begin{array}{c}\text { Regression } \\
\text { Residual } \\
\text { Total }\end{array}$ & $\begin{array}{c}89.798 \\
75.895 \\
165.693\end{array}$ & $\begin{array}{c}4 \\
145 \\
149\end{array}$ & $\begin{array}{c}22.449 \\
.523\end{array}$ & 42.890 & .000 \\
\hline
\end{tabular}

Table 5. Coefficients of Regression Analysis

\begin{tabular}{|c|c|c|c|c|c|c|}
\hline & \multirow{2}{*}{ Model } & \multicolumn{2}{|c|}{ Unstandardized Coefficients } & \multirow{2}{*}{$\begin{array}{c}\begin{array}{c}\text { Standardized } \\
\text { Coefficients }\end{array} \\
\text { Beta } \\
\end{array}$} & \multirow[t]{2}{*}{$\mathrm{t}$} & \multirow{2}{*}{ Sig. } \\
\hline & & B & Std. Error & & & \\
\hline (Constant) & \multirow{5}{*}{ Teaching } & .123 & .405 & & .304 & .762 \\
\hline $\mathrm{OC}$ & & .378 & .115 & .295 & 3.298 & .001 \\
\hline LD & & .101 & .101 & .090 & .894 & .373 \\
\hline IT & & .033 & .033 & .033 & .375 & .708 \\
\hline EM & & .430 & .430 & .404 & 3.819 & .000 \\
\hline (Constant) & \multirow{5}{*}{ Research } & .383 & .428 & & .896 & .372 \\
\hline $\mathrm{OC}$ & & .249 & .121 & .186 & 2.051 & .042 \\
\hline LD & & -.092 & .120 & -.078 & -.765 & .446 \\
\hline IT & & .078 & .092 & .075 & .848 & .398 \\
\hline EM & & .667 & .119 & .602 & 5.606 & .000 \\
\hline (Constant) & \multirow{5}{*}{ Citation } & .855 & .469 & & 1.824 & .070 \\
\hline $\mathrm{OC}$ & & .277 & .133 & .207 & 2.089 & .038 \\
\hline LD & & -.258 & .131 & -.219 & -1.963 & .052 \\
\hline IT & & .049 & .101 & .047 & .488 & .626 \\
\hline EM & & .728 & .130 & .655 & 5.585 & .000 \\
\hline (Constant) & \multirow{5}{*}{ International Outlook } & -.515 & .543 & & -.949 & .344 \\
\hline $\mathrm{OC}$ & & .529 & .154 & .346 & 3.442 & .001 \\
\hline LD & & -.319 & .152 & -.237 & -2.095 & .038 \\
\hline IT & & .276 & .117 & .232 & 2.367 & .019 \\
\hline EM & & .474 & .151 & .374 & 3.144 & .002 \\
\hline (Constant) & \multirow{5}{*}{ Industry Income } & .833 & .415 & & 2.007 & .047 \\
\hline $\mathrm{OC}$ & & .040 & .118 & .031 & .341 & .734 \\
\hline LD & & -.009 & .116 & -.008 & -.081 & .935 \\
\hline IT & & .229 & .089 & .231 & 2.568 & .011 \\
\hline EM & & .559 & .115 & .527 & 4.839 & .000 \\
\hline
\end{tabular}


Table 3 perceived that $56.8 \%$ of teaching, $55.5 \%$ of research, $54.2 \%$ of industry income, $46.9 \%$ of citation, and $45.3 \%$ of international outlook are due to KM enablers (organizational culture, leadership, information technology, and employee motivation).

Table 4 demonstrates that teaching, research, citation, international outlook, and industry income are all significant equal to 0.000 which are less than the value of alpha 0.05 , and therefore the models are fit and valid.

Linear regression in Table 5 reveals that positive and significant relationship exists between employee motivation and performance outcomes in terms of teaching, research, citation, international outlook, and industry income. As a result, employee motivation has positive and significant impacts on teaching, research, citation, international outlook, and industry income. Another positive and significant relationship exists between organizational culture and performance outcomes in terms of teaching, research, citation, and international outlook. As a result, organizational culture has positive and significant impacts on teaching, research, citation, and international outlook. Also, positive and significant relationship exists between information technology and international outlook and industry income; therefore IT has positive and significant impacts on international outlook and industry income. However, negative and significant relationship exists between leadership and international outlook; therefore leadership has negative and significant impacts on international outlook.

The coefficients of OC are 0.378 and EM is 0.430 which means that for every unit progress in OC and EM the teaching performance would be accelerated by 0.378 and 0.430 . Likewise, for every one unit progress in OC and EM the research performance would be accelerated by 0.249 and 0.667. Also, for every one unit progress in OC and EM the performance in citation would be accelerated by 0.277 and 0.728 . In addition, for every one unit progress in OC, LD, IT, and EM the performance in international outlook would be accelerated by $0.529,-0.319,0.276$, and 0.474 respectively. Lastly, for every one unit progress in IT and EM the industry income performance would be accelerated by 0.229 and 0.559 .

\section{Discussion}

The findings of the study demonstrate that employee motivation have positive and significant impacts on performance outcomes in terms of teaching, research, citation, international outlook and industry income. This signifies that if the state university provides reward systems it produces enhanced employee outcomes which in turn leads to better performance outcomes (teaching, research, citation, international outlook, and industry income). The study is in line with previous studies like Kwapong et al. [30] which investigated the effect of motivation on the performance of teaching staff in Ghanaian Polytechnics and found positive significant relationship between motivation and performance. Alfagira [31] investigated the role of motivation in teaching, research and publication in one university in Libya and established positive significant relationship between motivation (job satisfaction, work stress, salary, reward, promotion, and organizational policy) and the performance (teaching, research and publication). In addition, Aljaf and Sadq [32] studied the impact of employee motivation on organizational performance at one university in Iraq and found that promotional opportunities and rewards leaded to increase the performance of the organization. Likewise, Mwabu and Were [33] concluded positive and significant influence of reward management, training and development, work environment, and career growth as employee motivation on the performance of research institutes in Kenya.

This research also revealed that organization culture has positive and significant impacts on the four performance outcomes (teaching, research, citation, and international outlook). This means that if the state university practices the culture of creating, sharing, and applying knowledge the faculty and staff perform better in teaching, research, citation, and international outlook. The results are similar to the reports of Alshery [34] that organizational culture contributes significant positive impacts on employee performance of higher education sector of the Kingdom of Saudi Arabia. In the study of Raimi [35] found that organizational culture influences sustainability performance in higher education institutions in Nigeria. Idris [36] found that in higher education of Indonesia, organizational culture positively and significantly influences organizational performance such as level of absorption of the budget, level of income from research grants, level of accreditation, number of student admissions, number of lecturers' research, and community service. In the case of Indonesians Islamic Higher Education Institutions, Hambali and Idris [37] also found that organizational culture highly influences organizational performance. Also, Taye et al. [38] confirmed that in one state university in Beijing, organizational culture (environment, mission, leadership, information, strategy, and socialization) strongly influences the individual performance and overall performance of the university. In Iraq, organizational culture (teamwork and innovation capability) plays significant role to the performance (job performance and education quality) of higher education institutions [39]. Results of the studies conducted in Saudi Arabia, Nigeria, Indonesia, China, and Iraq are contrasted in the findings in Palestine where organizational culture is not significantly related to the performance of higher education institutions [40].

In accordance with the results of this study, information technology has positive and significant impacts on international outlook and industry income. This signifies 
that state university may establish information technology infrastructure to achieve better performance in international outlook (increase foreign students, foreign staff, and international collaboration) and industry income (increase innovations and inventions). The competitive advantage of an organization can be improved through IT [41]. Maria et al. [41] suggested that IT process requires measurements to indicate the IT performance in order to achieve the vision, mission, goals, and objectives of the organization.

However, leadership as a key factor of KM has negative and significant impacts on international outlook. This signifies that hiring people, supporting different programs, utilizing knowledge created by the faculty members, and implementing strategic plan in able to increase the numbers of foreign students and employees and international collaborations were affected by four years of leadership of the University President. This means that as the leadership changes, the strategies in internationalization were also changed. Leadership is one of the most important factors that affect high performance of universities and intermediate colleges in Palestine [42]. Leaders as suggested by Mastrangelo et al. [43] should focus on enhancing professional and personal leadership in order to positively impact organizational success. This research was conducted in the two school districts in New York and found that leadership has an impact on the intentions of the employees to cooperate which in turn resulted in high performance outcomes. Another research conducted in public universities in Ghana found that leadership supports improvement in the organizational performance [44].

\section{Conclusion}

This research concludes that among the four KM enablers only employee motivation is found to be a positive and significant predictor of the five measures of performance outcomes: (1) teaching, (2) research, (3) citation, (4) international outlook, and (5) industry income. Organizational culture as $\mathrm{KM}$ enabler is found to be a positive and significant predictor of teaching, research, citation, and international outlook. The KM enabler information technology is found to be a positive and significant predictor of international outlook and industry income while the KM enabler leadership is found to be a negative and significant predictor of international outlook.

\section{Limitation and Future Research}

The sample size of the study is relatively small to generalize the results. Future research can be conducted by replicating this study in a large sample size. The numbers of higher education institutions involved in the study are only three state universities. Future research can be conducted in all state universities and colleges. Other types of higher education institutions such as private and local universities and colleges may also consider in the future research. This research studied only the five measures in determining the best universities in the world while further studies may include accreditation and licensure examinations to detect organizational performance. This study employed quantitative method and in the future studies can adopt mixed method research (qualitative and quantitative).

\section{REFERENCES}

[1] Geraud Servin, Caroline De Brun. "ABC of Knowledge Management," NHS National Library for Health: Specialist Library, Vol. 20, 2005.

[2] Leila A. Halawi, Jay E. Aronson, Richard V. McCarthy. "Resource-based View of Knowledge Management for Competitive Advantage," The Electronic Journal of Knowledge Management, Vol. 3, No. 2, pp. 75 - 86, 2005.

[3] C. Ramanigopal. "Knowledge Management Strategies in Higher Education," International Journal of Advanced Research in Management, Vol. 3, No. 1, pp. 20 - 29, 2012.

[4] Apurva Anand, M. D. Singh. "Understanding Knowledge Management," International Journal of Engineering Science and Technology, Vol. 3, No. 2, pp. 926 - 939, 2011.

[5] William R. King. "Knowledge Management and Organizational Learning," Annals of Information Systems, Vol. 4, pp. 3 - 13, 2009.

[6] Ali Akbar Ahmadi, Farokh Ahmadi. "Knowledge Management in Iranian University (Case Study Shushtar Univercity)," Interdisciplinary Journal of Contemporary Research in Business, Vol. 4, No. 5, pp. 653 - 667, 2012.

[7] Nguyen Ngoc-Tan, Ales Gregar. "Knowledge Management and Its Impacts on Organisational Performance: An Empirical Research in Public Higher Education Institutions of Vietnam," Journal of Information \& Knowledge Management, Vol. 18, No. 02, pp. 1950015-1-1950015-29, 2019. DOI: $10.1142 / \mathrm{S} 0219649219500151$.

[8] Chin-Mou Cheng, Rong-Lain Ho, Yu-Hsuan Chao. "The Application of Knowledge Management to the Universities' Technologic General Education in Taiwan," WSEAS Trans on Information Science \& Applications, Vol. 1, No. 1, 417 $422,2004$.

[9] Adebowale Ojo. "Knowledge Management in Nigerian Universities: A Conceptual Model," Interdisciplinary Journal of Information, Knowledge, and Management," Vol. 11, No. 2, pp. 331 - 345, 2016.

[10] Rodrigo Lozano, Rebeka Lukman, Francisco J. Lozano, Donald Huisingh, Wim Lambrechts. "Declarations for Sustainability in Higher Education: Becoming Better Leaders, through Addressing the University System," Journal of Cleaner Production, Vol. 48, pp. 10 19, 2014. DOI: 10.1016/j.jclepro.2011.10.006.

[11] Mohd Ghazali Mohayidin, Nor Azirawani, Man 
Norfaryanti Kamaruddin, Mar Idawati Margono. "The Application of Knowledge Management in Enhancing the Performance of Malaysian Universities," Electronic Journal of Knowledge Management, Vol. 5, No. 3, pp. 301 - 312, 2007.

[12] Mamta Bhusry, Jayanti Ranjan. "Implementing Knowledge Management in Higher Educational Institutions in India: A Conceptual Framework," International Journal of Computer Applications, Vol. 29, No. 1, pp. 34 - 46, 2011. DOI: $10.5120 / 3527-4805$.

[13] Jillinda J. Kidwell, Karen Vander Linde, Sandra L. Johnson. "Applying Corporate Knowledge Management Practices in Higher Education," Educause Quarterly, Vol. 23, No. 4, pp. $28-33,2000$.

[14] Lisa A. Petrides, Lily Nguyen. Knowledge Management Trends: Challenges and Opportunities for Educational Institutions. In Knowledge Management and Higher Education: A Critical Analysis (pp. 21-33). IGI Global, 2006. DOI: 10.4018/978-1-59140-509-2.ch002.

[15] Abbas Khakpour. "Knowledge Management in Educational Organizations: Opportunities and Challenges," Paper presented at the 7th International Knowledge Management Conference, 2015.

[16] NG EE Ling, Rosni Bakar, Aminul Islam. "Awareness of Knowledge Management among Higher Learning Institutions: A Review," Advances in Environmental Biology, Vol. 8, No. 9, pp. 436 - 439, 2014.

[17] B. R. Senthil Kumar, M. Thiagarajan, P. Maniiarasan, J. Prasanth, G. Abilesh, D. Srinivasan. "Enhancement in Higher Education with Knowledge Management," International Journal of Science, Engineering and Technology Research, Vol. 2, No. 3, pp. 569 - 573, 2013.

[18] Kazi Mostak Gausul Hoq, Rowshan Akter. "Knowledge Management in Universities: Role of Knowledge Workers," Bangladesh Journal of Library and Information Science, Vol. 2, No. 1, pp. 92 - 102, 2012. DOI: 10.3329/bjlis.v2i1.12925.

[19] Vittal S. Anantatmula, Shivraj Kanungo. "Modeling Enablers for Successful KM Implementation," Paper presented at the IEEE 40th Annual Hawaii International Conference on System Sciences, 2007. DOI: 10.1109/HICSS.2007.387.

[20] C. W. Holsapple, K. D. Joshi. “An Investigation of Factors that Influence the Management of Knowledge Organizations," Journal of Strategic Information Systems, Vol. 9, pp. 235 - 261, 2000.

[21] John Omogeafe Ohiorenoya, Ohimai Friday Eboreime. "Knowledge Management Practices and Performance in Nigerian Universities," European Scientific Journal, Vol. 10, No. 16, pp. 400 - 416, 2014.

[22] Kalaimagal Ramakrishnan, Norizan Mohd Yasin. "Knowledge Management System and Higher Education Institutions," International Proceedings of Computer Science and Information Technology, Vol. 37, No. 1, pp. 67 $-71,2012$.

[23] Peggy D. Brewer, Kristen L. Brewer. "Knowledge Management, Human Resource Management, and Higher Education: A Theoretical Model," Journal of Education for
Business, Vol. 85, No. 6, pp. 330 - 335, 2010. DOI: $10.1080 / 08832321003604938$.

[24] Rahmad Sukor Ab Samad, Mohamed Iskandar Rahmad Sukor, Darwyan Syah. "Determining Contributors of Performance in Malaysian High Performing Schools: In the Light of Knowledge Management and Organizational Learning," International Journal for Innovation Education and Research, Vol. 2, No. 5, pp. 13 - 19, 2014. DOI: 10.31686/ijier.vol2.iss5.180.

[25] Sharimllah Devi Ramachandran, Siong Choy Chong, Binshan Lin. "Perceived Importance and Effectiveness of KM Performance Outcomes: Perspective of Institutions of Higher Learning," International Journal of Innovation and Learning, Vol. 5, No. 1, pp. 18 - 37, 2008.

[26] UNESCO Institute for Statistics. Higher Education in Asia: Expanding Out, Expanding Up: The Rise of Graduate Education and University Research. UNESCO, 2014.

[27] Sharimllah Devi Ramachandran, Siong-Choy Chong, Kuan-Yew Wong. "Knowledge Management Practices and Enablers in Public Universities: A Gap Analysis," Campus-Wide Information Systems, Vol. 30, No. 2, pp. 76 - 94, 2013. DOI $10.1108 / 10650741311306273$.

[28] Times Higher Education. World University Rankings, 2018. https://www.timeshighereduucation.com

[29] Joseph F. Hair Jr., G. Tomas M. Hult, Christian Ringle, Marko Sarstedt. A Primer on Partial Least Squares Structural Equation Modeling (PLS-SEM). Sage Publications, 2016.

[30] Lipsey Samuel Appiah Kwapong, Emmanuel Opoku, Fukuo Donyina. "The Effect of Motivation on the Performance of Teaching Staff in Ghanaian Polytechnics: The Moderating Role of Education and Research Experience," Global Journal of Human Resource Management, Vol. 3, No. 6, pp. 30 - 43, 2015.

[31] Salem Gdwar A. Alfagira. "The Factors that Affect Academic Staff to Improve their Performance at Sebha University, Libya: The Role of Motivation as a Mediator,' Journal of Education and Social Sciences, Vol. 13, No. 2, pp. $18-31,2019$.

[32] Nadema Aljaf, Zana Majed Sadq. "The Impact of Employee Motivation on Organisational Performance: An Empirical Study at Hayat University-Erbil/Iraq," Journal for Studies in Management and Planning, Vol. 1, No. 10, pp. 83 - 93, 2015.

[33] Grace Muthoni Mwabu, Susan Were. "Influence of Employee Motivation on Performance in Selected Research Institutions in Nairobi City County, Kenya," International Academic Journal of Human Resource and Business Administration, Vol. 3, No. 6, pp. 354 - 374, 2019.

[34] Walled Bin Rashed Alshery, Fais Bin Ahmad, Abdullah Kaid Al-Swidi. "The Moderating Effect of Role Ambiguity on the Relationship of Job Satisfaction, Training and Leadership with Employee Performance," International Journal of Business Administration, Vol. 6, No. 2, pp. 30 41,2015 .

[35] Bolaji Raimi. "An Investigation of the Relationship between Organisational Culture and Sustainability 
Performance in Higher Education Institutions in Ilorin, Nigeria (Doctoral dissertation, Cardiff Metropolitan University)," 2020.

[36] Idris Idris. "Exploring Organizational Culture, Quality Assurance, and Performance in Higher Education," MEC-J (Management and Economics Journal), Vol. 3, No. 2, pp. 166 - 181, 2019. DOI: 10.18860/mec-j.v3i2.7529.

[37] Muh Hambali, Idris. "Transformational Leadership, Organizational Culture, Quality Assurance, and Organizational Performance: Case Study in Islamic Higher Education Institutions (IHEIS)," Journal of Applied Management, Vol. 18, No. 3, pp. 572 - 587, 2020. DOI: 10.21776/ub.jam.2020.018.03.18.

[38] Markos Taye, Guoyuan Sang, Abdulghani Muthanna. "Organizational Culture and Its Influence on the Performance of Higher Education Institutions: The Case of a State University in Beijing," International Journal of Research Studies in Education, Vol. 8, No. 2, pp. 77 - 90, 2019. DOI: $10.5861 /$ ijrse.2019.3026.

[39] Mohammed Ahmed Waham, Rafiduraida Abdul Rahman, Wan Salmuni Wan Mustaffa. "The Effect of Transformational Leadership on Organizational Performance through the Mediating Role of Organizational Culture in Higher Education Institutions in Iraq," International Journal of Psychosocial Rehabilitation, Vol. 24, No. 8, pp. 13638-13651, 2020. DOI: 10.37200/IJPR/V24I8/PR281352.

[40] Haim Hilman, Mohammed Siam. "The Influence of
Organizational Structure and Organization Culture on the Organizational Performance of Higher Educational Institutions: The Moderating Role of Strategy Communication," Asian Social Science, Vol. 10, No. 13, pp. 142 - 154, 2014. DOI: 10.5539/ass.v10n13p142.

[41] Evi Maria, Charitas Fibriani, Lina Sinatra. "The Measurement of Information Technology Performance in Indonesian Higher Education Institutions in the Context of Achieving Institution Business Goals Using Cobit Framework version 4.1 (Case Study: Satya Wacana Christian University, Salatiga)," Journal of Arts, Science \& Commerce, Vol. 3, No. 3, pp. 9 - 19, 2012.

[42] Samy S. Abu Naser, Mazen J. Al Shobaki, Youseff M. $\mathrm{Abu}$ Amuna. "Promoting Knowledge Management Components in the Palestinian Higher Education Institutions - A Comparative Study," International Letters of Social and Humanistic Sciences, Vol. 73, pp. 42 - 53, 2016.

[43] Angelo Mastrangelo, Erik R. Eddy, Steven J. Lorenzet. "The Relationship between Enduring Leadership and Organizational Performance," Leadership \& Organization Development Journal, Vol.35, No.7, 590-604, 2014. DOI: 10.1108/LODJ-08-2012-0097.

[44] Lawrence Yaw Kusi, Alexander Opoku-Danso, Ebenezer Afum. "Improving Performance of Public Universities in Ghana through Talent Management: Does Leadership Support Matter?," Global Journal of Management and Business Research, Vol. 20, No. 10, pp. 41 - 68, 2020. 